should be made to build up a regular short-wave service to the countries of the British Empire, trusting to an improvement in both transmission and reception to make it justifiable. The bare principles on which the first station was designed did not differ in essentials from the much bigger stations which several countries are operating to-day. Wavelengths in several groups within the limits of 13 to 50 metres are still used, except for the 100-metre transmissions to Canada, which are only used to overcome somewhat special conditions. Again, the principle of transmitting on directional beams, taking various parts of the world in turn, following the clock, still more or less applies to-day. No striking new invention has arisen to revolutionize the technique, but a great deal has been learned about the design of aerials, and how to construct them so that they radiate a beam of the right width and depth and as nearly as possible at the right angle to the earth, so that they will be reflected back to earth by the ionosphere, and arrive in that part of the world where they are intended to be received. The first experimental transmitter used only one wave-length, and the new station completed ten years ago used eight wave-lengths. We are now using no less than forty-four. The hours of transmission, too, are strikingly different; the first station with its two transmitters sent out twenty-three transmitter hours per day; but now the number of transmitter hours per day is more than three hundred and fifty-six. There was only one language used with the first station, as against nearly fifty at present.

\section{Reception and Rediffusion}

Bra developments have also taken place at the receiving end. At the beginning, short-wave receivers were looked upon almost as scientific instruments which were of little use to people with no particular interest in technical matters. Even super-heterodyne receivers were comparatively rare only ten years age, and undoubtedly it was the development of this type of receiver, with efficient automatic volume control and simplified tuning, which has done a great deal to convert a highly speculative undertaking into what may now fairly be called a firmly established institution. Another important factor has been the growth in the rediffusion of programmes by wires connecting a number of houses to a central receiving station. Such a station can be an elaborate and costly affair embodying the very best technique in short-wave reception. Such undertakings exist in many parts of the Empire, for example, Malta, and notably in the West African colonies. Somewhat similar advantages are gained by rebroadcasting through a local broadcasting station. The Empire and North American Services transmit for a total of nearly 149 hours a week, and are rebroadcast by wireless stations for nearly 55 hours, and when we include wireless exchanges this figure rises to more than 130 hours. Two pioneers who were instrumental in establishing wireless exchanges in several of the Colonies were Sir Arnold Hodson, recently governor of the Gold Coast, and Mr. F. Byron, an engineer in the Colonial Service.

\section{The Future}

Arr this development, both on the transmitting and receiving side, has taken place well inside ten years, and is not solely due to the War. What will be the future of short-wave broadcasting ? Will people still go on listening and searching to see what they can find coming from distant countries ? There is not much doubt that for some time they will, since news must be foremost in everybody's mind for many years to come. The question remains what will happen when and if news becomes a matter of less pressing importance to the whole world? Is shortwave broadcasting capable of further development, purely as a means of recreation and enjoymont? Whether the results obtainable by this means will. ever be equalled by an ordinary direct listener in his home would at first sight seem doubtful, but if the progress in the next ten years is anything like that in the last ten years, we may look forward to the day when reception from far-off countries is almost as good as from the local station, and a few years after that we may even see the addition of pictures.

\section{Nottingham Open Forum}

AN experiment suocessfully conducted in Nottingham during the last two months has aroused considerable local interest, and might well find favour in other towns and cities. The Nottingham Open Forum was sponsored by the British Council, in cooperation with University College, Nottingham, and the Ministry of Information, as an attempt to attain a better understanding and closer contact between local residents and visitors from overseas, both civilians and allied troops; and to stimulate informative discussion on matters of general interest. A series of meetings on 'Brains Trust' lines, but on a broad international basis, was arranged, and organizations such as the International Centre, the British Empire Club, the Polish 'Troops' Club, the Rotarians, Y.M.C.A. and Y.W.C.A., etc., were invited to co-operate, as well as the general public. It was felt that the public to-day prefers to be stimulated to think for itself rather than to be 'lectured at' and told what to think. The promoters of the Nottingham Open Forum have no political bias and are therefore free in their choice of subjects and speakers, and the members of each panel can express their views without reserve however eontroversial they happen to be. This type of meeting naturally has a much wider appeal than the usual 'publis meeting' which is seldom free from the taint of propaganda. The information-seeking publio is surely entitled to be at least as well catered for as the amusement-seeking public, and the successful presentation of any open forum or 'Brains Trust' depends largely on the care with which it is organized.

In Nottingham, "International Relations" was chosen for the first Open Forum; the audience was then invited to submit suggestions for future topias. This resulted in a wide variety of subjects from which the committee selected those of most general interest, including "Local Government", "The British Commonwealth", "Science and Modern Life", "Books, Writers and Readers", "Social Democracy", "Education : for whom and for what ?", "Town and Country Planning", "National and International Law", etc. It is of obvious importance that the panel of speakers should be well-balanced and as representative as possible of the various aspects of each topic under discussion. For example, with "Local Government" as the subject, the panel consisted of a city counoillor (Independent), the Deputy Town Clerk, an Amerioan city manager, a woman member of the City Council (Conservative), with a Labour M.P. (ex-chairman of 